\title{
Social Security and Private Sickness Insurance in Spain
}

\author{
by Ignacio $\mathbf{H}$. de Larramendi y Montiano*
}

\section{Introduction}

Under the Spanish "General Health Law", obligatory social security should cover the entire population.

At present, the health insurance provided by social security covers the contingencies of $95 \%$ of the Spanish population. The health provisions are handled through the National Health Institute (Instituto Nacional de la Salud) or the services that have now been transferred to the Autonomous Communities of Catalonia and Andalusia, as well as the Social Institute of the Navy and the Workmen's Compensation Mutuals.

Social security is financed through the contributions of employers and workers, which are supplemented by resources from the State itself, since there is a normal deficit of operations.

However, social security is not the only organisation providing health assistance. A significant part of the Spanish population, although covered by social security and paying their contributions to it, have opted for a second coverage under a voluntary insurance scheme with insurance companies that provide such services.

These organisations are financed through the payment of the premiums or contributions, and may be "Mutualidades de Previsión Social", Mutual Companies, Insurance Cooperatives and Stock Companies.

The "Mutualidades de Previsión Social" are non-profit-making organisations that may have their own assistance facilities: hospital and clinics, or doctors day care clinics. In general, the rest of the private insurance organisations do not provide direct assistance, to their clients, with some exceptions.

Apart from the "health assistance insurance" there are also the so-called sickness insurance policies, whose provisions consist of cash indemnity in the event of sickness, accident, hospitalisation, etc.

Thus, we have a situation in Spain in which obligatory national insurance that is offered to the majority of the population, exists alongside other forms of voluntary private insurance.

${ }^{*}$ Chairman, Mapfre, Madrid: Test presented at the General Assembly of the Geneva Association, Berlin, June 16, 1987. 
Table 1: Insured Population by Insurance Organisation

(thousand persons)

\begin{tabular}{|c|c|c|c|c|c|c|}
\hline \multirow[b]{2}{*}{ Year } & \multicolumn{4}{|c|}{ 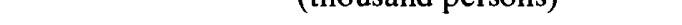 } & \multirow[b]{2}{*}{$\begin{array}{c}\text { Private } \\
\text { Insurance } \\
\text { Orgs. }\end{array}$} & \multirow[b]{2}{*}{$\begin{array}{c}\% \\
\text { Insured } \\
\text { Population }\end{array}$} \\
\hline & $\begin{array}{c}\text { Social } \\
\text { Security }\end{array}$ & $\begin{array}{c}\% \\
\text { Insured } \\
\text { Population }\end{array}$ & $\begin{array}{c}\text { Mutuas de } \\
\text { Prevision } \\
\text { Social* }^{*}\end{array}$ & $\begin{array}{c}\% \\
\text { Insured } \\
\text { Population }\end{array}$ & & \\
\hline 1980 & 31.107 & 83,1 & - & - & $\longrightarrow$ & - \\
\hline 1981 & 31.647 & 84,0 & - & 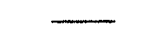 & 4.563 & 12,1 \\
\hline 1982 & 32.527 & 86,0 & 1.119 & 3,0 & - & \\
\hline 1983 & 33.067 & 86,9 & 1.094 & 2,9 & 5.177 & 13,6 \\
\hline 1984 & 35.320 & 92,3 & 1.024 & 2,7 & 4.817 & 12,6 \\
\hline
\end{tabular}

* Mutual Benefit Societies

Source: Social security balance sheets and accounts.

Federación de Mutualidades de Previsión Social. UNESPA.

The Table 1 shows the volumen of the population insured by each of the organisations: social security and private organisations. One can observe that a high percentage of the population is covered in their health assistance needs through social security. Nonetheless, as pointed out above, one can also see that much higher percentages than those not covered by social security are insured with voluntary or private insurance organisations, indicating this situation of "double insurance" amongst the Spaniards, is partly due to the low esteem in which some segments of the population hold the quality of the public health services.

In 1984, almost 6 million (15\%) persons were insured for health assistance through "Mutualidades de Previsión Social" or private insurance organisations. Approximately $2.7 \%$ of the persons were assisted by "Mutualidades de Prevision Social" whilst the remaining $12.6 \%$ were with other private insurance organisations. This distribution is very similar to that existing at present and means that $15 \%$ of the Spanish population is insured for health assistance independently from the social security scheme.

Spanish social security used to provide $100 \%$ cover of the prescriptions. Nowadays it covers approximately $40 \%$, the rest being paid for by the user.

In the private insurance organisations and mutual societies, it is not usual for prescription costs to be covered.

We should also point out that social security does not cover mental health services, which are in some cases provided by the "Provincial Councils (Diputaciones)" and that it gives very limited assistance - almost non-existent - for odontological and geriatric services.

\section{Financing}

Spanish Social Security is financed, as we said above, by the contributions from companies and workers. The contributions for retirement costs and pensions and health assistance used to be differentiated, but they are now all mixed together, the company contributing $24 \%$ of the wages or salaries it gives its workers, and the workers $4.80 \%$ of their wages. This means that the total contributions amounts to nearly $29 \%$ of wages or salaries at present.

Social Security expenditure on health provisions is currently nearly a billion pesetas a year. 
We should also comment on the fact that, despite the high level of contributions, Spanish Social Security runs at a loss at present, having shown a progressively growing deficit over the last few years, such that, apart from the contributions from employers and workers, regular yearly subsidies were needed from the Government, out of the General Budget.

\section{Private Insurance Organisations}

Private insurance organisations have about 2 millions policies for health assistance. In 1986, their revenues in premiums was 69.000 million pesetas.

The Table 2 shows the growth in such premiums from 1980 to 1984.

Table 2: Health Assistance from private Insurance Organisations ${ }^{1}$

\begin{tabular}{cccccc} 
Year & $\begin{array}{c}\text { No. of } \\
\text { Policies }\end{array}$ & $\begin{array}{c}\text { Premiums }^{2} \\
\text { Paid in }\end{array}$ & $\begin{array}{c}\text { Expenditure }^{2} \\
\text { on Services }\end{array}$ & $\begin{array}{c}\text { Premiums } \\
\text { per Policy }\end{array}$ & $\begin{array}{c}\text { Expenditure } \\
\text { per Policy }\end{array}$ \\
\hline 1980 & 1.756 .565 & 28.146 & 22.998 & 16.023 & 13.093 \\
1981 & 1.643 .715 & 34.729 & 25.269 & 21.128 & 15.373 \\
1982 & 1.808 .216 & 40.689 & 32.581 & 22.502 & 18.018 \\
1983 & 1.826 .364 & 48.250 & 39.827 & 26.419 & 21.807 \\
1984 & 1.740 .586 & 53.354 & 44.448 & 30.653 & 25.536 \\
\hline
\end{tabular}

${ }^{1}$ Excluding Mutualidades de Previsión Social.

2 In million pesetas.

Source: UNESPA

The sum of the health services provided is currently about 50.000 million pesetas, which figure represents slightly more that $5 \%$ of the total health expenditure of social security.

As is to be expected, these organisations are financed through the premiums they charge the persons they insure.

\section{Provision of Assistance}

Social Security, althought the main insurer, does not have sufficient assistance resources to cope with its clients.

Only $34 \%$ of hospital beds belong to Social Security hospitals. The rest of the needs are covered by Social Security with agreements on assistance services with other public bodies or private hospital or clinics.

The private insurance organisations deal with their clients at private clinics and doctors' offices, since they do not normally have their own facilities.

"Mutualidades de Previsión Social" mainly give assistance in their own facilities. The mutual societies that have their own hospitals usually provide assistance through agreements with Social Security. 
Finally, we would say that the health assistance premiums represented $12.8 \%$ of the total of Spanish insurance premiums in 1986, excluding life insurance.

Table 3 showing the growth in health insurance premiums over the last four years, whilst Table 4 shows what share these have of the entire insurance market in Spain.

Table 3: Private Health Insurance Organisations Premiums (in millions pesetas)

\begin{tabular}{llr} 
& & Int. \% \\
1980 & 28.146 & \multicolumn{23}{c}{. } \\
1981 & 34.729 & 17,16 \\
1982 & 40.689 & 18,58 \\
1983 & 48.250 & 10,58 \\
1984 & 53.354 & 9.55 \\
1985 & 58.450 & 18,43 \\
1986 & 69.221 &
\end{tabular}

Table 4: Distribution of Insurance Premiums by Branch of Insurance (excl. Life Insurance) in 1986

\begin{tabular}{|c|c|c|c|}
\hline Branch & $\begin{array}{c}\text { Premiums } \\
\text { (million } \\
\text { pesetas) }\end{array}$ & $\begin{array}{c}\% \text { of } \\
\text { Total } \\
\text { Premiums }\end{array}$ & $\begin{array}{c}\% \\
\text { Growth }\end{array}$ \\
\hline \multicolumn{4}{|l|}{ Automobiles: } \\
\hline - Voluntary & 163.315 & 30,22 & 37,1 \\
\hline - Obligatory & $48.081,4$ & 8,90 & 6,1 \\
\hline Health assistance & $69.221,7$ & 12,81 & 18,4 \\
\hline Multi-risk & $47.766,6$ & 8,84 & 28,4 \\
\hline Personal accident & $44.957,5$ & 8,32 & 13,1 \\
\hline Fire & $39.837,5$ & 7,37 & 1,2 \\
\hline Burial & $33.432,6$ & 6,19 & 22,2 \\
\hline Transport & 31.200 & 5,77 & $-1,5$ \\
\hline Third Party liability & $14.631,5$ & 2,71 & 27,6 \\
\hline Credit & $9.090,3$ & 1,68 & 6,1 \\
\hline Agriculture insurance & $7.978,2$ & 1,48 & 33,3 \\
\hline Theft & $6.379,2$ & 1,18 & 3,5 \\
\hline Legal defense & $5.986,2$ & 1,11 & 2,5 \\
\hline Engineering & 5.831 & 1,08 & 26,7 \\
\hline Bonds & $3.971,3$ & 0,70 & 6,1 \\
\hline Loss of profits & $2.620,9$ & 0,48 & 10,3 \\
\hline Sickness subsidies & $1.616,8$ & 0,30 & 18,3 \\
\hline Subsidies for loss of driving license & 771,4 & 0,14 & 16,1 \\
\hline Other branches & $3.941,8$ & 0,72 & 25,4 \\
\hline TOTAL & $540.450,9$ & $100 .-$ & 19,6 \\
\hline
\end{tabular}




\section{Workmen's Compensation}

After the above, that is self-explanatory, I wish to make some comments on a experience of hospital assistance that exists in Spain, within the Mapfre System itself. Mapfre Workmens' Compensation is a company integrated in the Social Security and fully separated, physically and legally of the rest of the Mapfre Companies, with about 300 beds, and 700 Medical and "Paramedical" professionals working for it.

The Spanish Workmens' Compensation system permits Private Mutuals to work autonomously but integrated in the Social Security. They contribute to it with $80 \%$ of their annual profits and dedicate the other $20 \%$ to the improvement of their services. The Spanish system is original and has inspired the system still in force in Chile, created before the Allende Presidency and which overcame the difficulties of the Allende and Pinochet regimes.

The Spanish system is considered the best to cover Workmen's Compensation in Spanish and Portuguese speaking countries. It leaves freedom for private hospitals with a high level of specialization. In spite of the present socialist Government, there is no intention to change the system because it is generally recognized that its service to the workers is better than the previous of private insurance companies and even to that of the Government Mutuals since Private Workmen's Compensation Mutuals are only allowed to insure private companies.

\section{Present Situation of Health Private System}

At present, in Spain, Health Medical Assistance, as a whole suffers a deep crisis because of some radicalisation of positions, in the defense of professional interests and in a sectarism towards the "statization" of Medicine. The consequence is a serious deterioration of the Health Assistance, both in the public and in certain aspects, in the private sector. In this one, because of an erroneus Tariff system, fortunately disappeared, which led many insurance companies to de-capitalization; these problems are now starting to find solutions.

The de-capitalization and the necessity of improving the Medical Assistance offer some possibilities for a reform, which is appealing to foreign insurers who consider the present situation favourable for a private operation.

Health Insurers - except in the case of strictly economic compensation coverages - are fully separated from the classic insurance market; none of the importante insurers offer Health Assistance coverage and, as it is the case of my company, they are reluctant no enter into a radicalized and politized field.

Some times I was asked why did MAPFRE not use its hospital experience in other fields of Medical Assistance. I wish to answer to this question in public: MAPFRE MUTUA PATRONAL DE ACCIDENTES DE TRABAJO (and all others Private Workmen's Compensation Mutuals) fully depend on the Government and the Social Security System and I do not deem it likely that they were authorized to extend to other fields. On the other hand, the high level of specialization of these hospitals - the basis of their success - offers a very different experience to that of general hospitals. But insurers must enter into the Medical Assistance area; firstly, because some of our colleagues work in it and because of two other reasons too: 
- The insurer is compelled to reduce the cost of its services, not only to compensate them; and this requires some supervision of the management of costs.

- As I have stated in other occasions, insurance must extend its activities out of the pure compensation field and towards the offer of complementary services, where it is able to give better and cheaper services than other exclusive providers of medical care.

The insurers' situation is contradictory; on one hand, they try to take some steps to extend the duration of the life of their policyholders' (checking-up Centers in Japan, that Mapfre is also launching in Spain now). On the other, the extension of life duration creates serious problems to Medical Assistance because it increases its costs.

\section{Conclusion}

FUNDACION MAPFRE is very concerned about this problem as one of the more serious of our society and has started some studies on Medical Assistance in Cuba, Venezuela and other countries and it will hold a Seminar in Madrid in October on this subject.

I wish to congratulate the Geneva Association, for the attention paid in this meeting to the Medical Assistance problem, one of the most important for humankind in the future. Once more, the Association suceeded in being the most outstanding international forum in the insurers' social responsabilites area.

Finally, I wish to say that the most efficient Medical Assistance situation depends on many factors of each country, but every one will only be able to reach its "optimum" when answering to the following questions:

- Is the existence of a health monopoly desirable?

- Is it possible that a private structure complements or substitutes in many cases the public medical structure?

- Is it convenient that the private medical and hospitals system had a commercial nature as now is the tendency in USA - or that it keeps its institutional nature as in many European countries? 